Session TA3-1

\title{
Building Better Student Resumes with a Simple and Effective Class Assignment
}

\author{
Michael Krall \\ Lone Star College - Montgomery \\ Paul Pastusek \\ Pastusek and Associates
}

\begin{abstract}
College and university faculty provide years of instruction to future engineers. Students are strenuously challenged in a variety of new and complex and topics. However, many of these knowledgeable and highly skilled students have never been educated in the most basic of job search skills - producing a resume. When asked to write and submit a resume to potential employers, students often submit a poor presentation (both in visual and verbal content) of their true experiences and abilities. For most students, the presentation does not cover experiences of interest to potential employers. Others have a tendency to "exaggerate" their experiences, believing the feigned content will help them secure a more rewarding job.
\end{abstract}

To address the need for better resumes, a multi-stage assignment was given to a small group of engineering students at Lone Star College - Montgomery. Students were first asked to submit a resume with minimal direction to be evaluated by their instructor. During the course of the assignment, students were also required to attend resume workshops and meet with the college's career center staff for further direction. After each meeting, a new resume was submitted, and students received feedback specific to each resume and group discussions covered general trends within the class. In the final stage of the assignment, resumes were collected and submitted to an engineering manager and human resources manager at a large engineering service company where the instructor had developed a close working relationship. These two professionals provided the final stage of feedback to students.

Over the span of this assignment, student resumes improved dramatically in content and presentation. The information offered was much more thorough and pertinent to the student objectives. In addition to developing better job search skills for the students, this project also connected students with a potential employer and provided the service company a pool of internship candidates.

\section{Introduction}

Ultimately, the goal of every engineering student is to start a career, and the traditional first step in the job search process is to create and distribute a resume. Unfortunately, given the fast pace of a typical workday, those making hiring decisions are severely time-limited and often spend only 15 to 30 seconds in the first scan of a typical resume ${ }^{1}$. Because the resume is most likely the prospective employee's singular contact with the employer, and since employers have so 
little time to spend with each resume, a neat, well-organized, and impressive resume is imperative.

However, where do engineering graduates learn resume-writing skills? Engineering degree plans lead students through courses totaling between 120 and 150 credit hours ${ }^{2}$ that are packed full of technical content. Considering that a majority of those degree hours must be dedicated to math, science, and core-curriculum courses, and that states are exerting more pressure to reduce credit hour requirements ${ }^{3}$, every hour of student contact is growing more precious. Can any engineering material be sacrificed so that significant time be dedicated to writing a successful resume? One option is to direct students to campus career centers, which often hold treasures of helpful information.

More recently, ABET accrediting standards have been amended so that program outcomes now incorporate "professional skills" ${ }^{4}$ including effective communication ${ }^{4,5}$. Obviously, this requirement calls for a focus on writing at some point in a student's degree, and writing a resume is a vital piece of professional communication, but teaching communication is often a time sink. To satisfy this requirement, a successful method for developing student resumes that uses existing resources and does not significantly impact class time is needed.

\section{The Process}

To encourage successful student resumes, an assignment was developed as part of a secondsemester Foundations of Engineering course at Lone Star College- Montgomery. This course focuses on engineering problem solving, computer programming solutions to engineering problems, physics concepts, and teaming. The results of adding a resume writing assignment to this course are discussed in this paper.

Through a series of iterations, ten students submitted resume drafts that were reviewed by a single faculty member, by a handful of career and writing center staff, and by two industry professionals. Students were asked to create a resume that could be used in an application for a summer internship. The assignment was given to the students in five parts that were spread over the course of six weeks. Each part is shown below as presented to the students:

Part 1: Create a Resume

- Write your resume so that it includes your objective, education, work experience, and skills.

- Print it in a presentable and attractive format.

Grade: Based on the completeness and presentability of your resume.

Part 2: Attend a Resume Seminar

- Attend one of the resume seminars in the Learning Center: Tuesday, February $26^{\text {th }}, 1-2$ PM in Building C, room C100G Friday, February $29^{\text {th }}, 1-2$ PM in Building C, room C100G

- If you are unable to attend one of those sessions, you can arrange an appointment with a career counselor in Building E.

Grade: Participation

Proceedings of the 2009 ASEE Gulf-Southwest Conference

Baylor University

Copyright (C) 2009, American Society for Engineering Education 
Part 3: Update your Resume

- Re-write a $2^{\text {nd }}$ draft of your resume using the information given at the seminar.

- Turn in your original resume (the graded copy) along with the $2^{\text {nd }} \mathrm{draft}$.

Grade: Based on the completeness, presentability, and updates to your resume.

Part 4: Attend "Resumania"

- Attend the "Resumania" session in Building A on Tuesday, March $18^{\text {th }}$.

- If you are unable to attend the session, you can arrange an appointment with a career counselor in Building E.

Grade: Participation

Part 5: Create a Final Resume

- Write a final draft of your resume using the information given at the seminar.

- Turn in your original resume along with the $2^{\text {nd }}$ draft (the graded copies) and final draft.

Grade: Will be evaluated by engineering managers from an industrial setting. Your grade will be based on feedback from the managers.

The reader may note that the grading tends toward generosity. Students must complete numerous difficult assignments within this course. Offering these easily achievable grades does not significantly impact the overall grades, and does promote participation in this project. Grading based on participation, completeness, and presentability also minimized the grading time required.

\section{Part 1: Creating a Resume}

The objective of the first assignment was to inspire the class to begin thinking about their resumes by writing one without guidance from faculty or career center staff. This first stage yielded predictable results. Student resumes did not follow commonly expected standards, and could be placed into one of three categories: much too lengthy, graphically disorganized, or the bare minimum of content.

Students in the "too lengthy" category recorded almost any fact related to any job experience they have had. The advisors at the LSC-Montgomery career center confirmed that engineers are notorious for attempting to make a life history out of a resume ${ }^{6}$. Figure 1 below demonstrates an example of one of these tomes. (In all example resumes, names have been changed to protect the less-than-innocent authors.) 


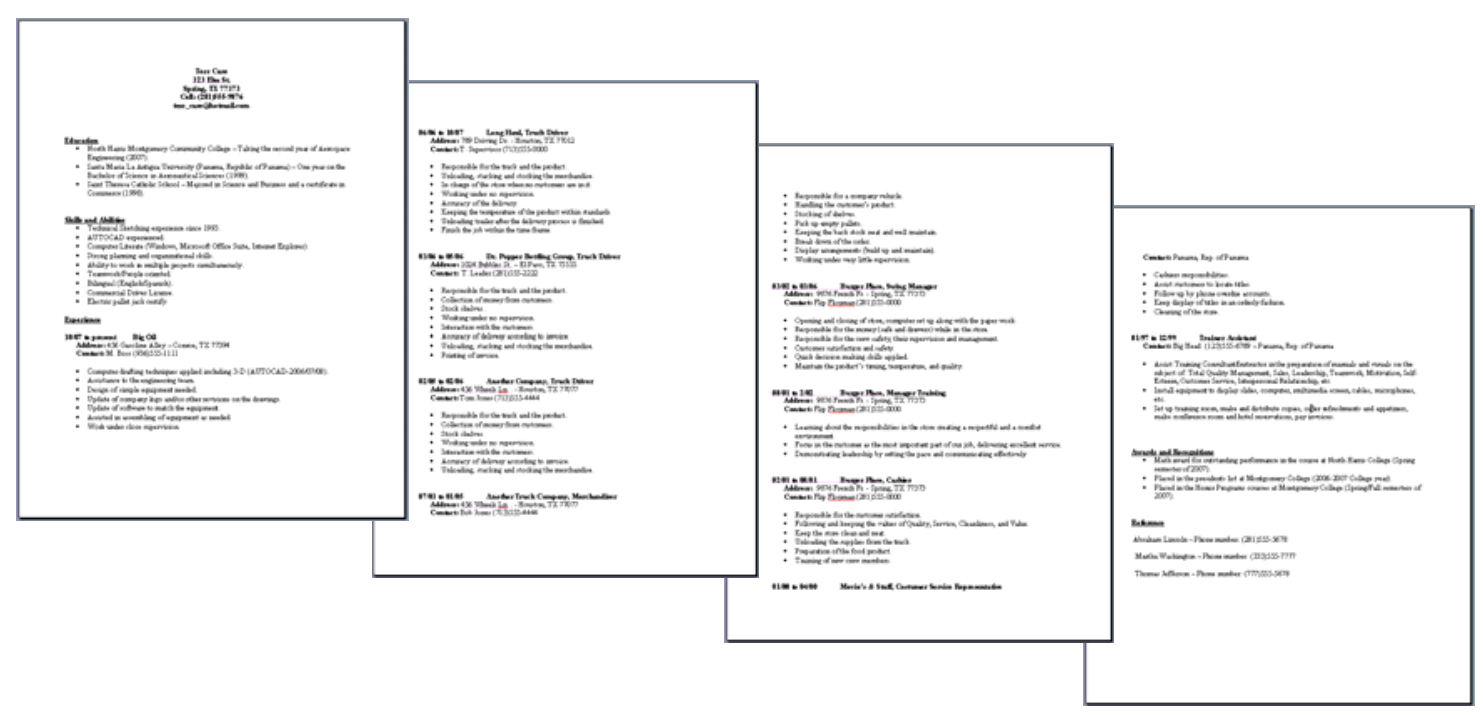

Figure 1. An Example of a LONG Resume

Many students are concerned when entering their first engineering graphics course because of their self-proclaimed lack of artistic talent. Sadly, some resumes supported this belief. Figure 2 shows some of the graphic design mistakes that students often make. "Mr. Puhl" alternates between two fonts for no apparent reason, font sizes for parallel items vary, too much white space makes his document look bare, and organizing his work history into two columns makes the information difficult to read. Most students exhibited at least one of these errors. 


\section{M. Pufl}

898 Main St., Hometown, TX77333

(713) 555-3333 example@yahoo.com

Objective:

My objective is to provide excellent and reliable service as a company member in many areas; including but not limited to technology and problem- solving applications as well as client to technician communications.

\section{Education:}

2001- Current:

Lone Star College - Montgomery

Pursuing BS in Petroleum Engineering

Graduated 1999:

Hometown High School

\section{Experience:}

Big Stuff Equipment Company:

2005 - Current

Owner/Operator

- Located and purchased valuable equipment wholesale

- Thoroughly researched and prepared items for resale at auction

- Processed all sale transactions and made sure all items were safely and properly shipped to the buyer

- Kept an extensive record of purchases and sales with Microsoft Excel spreadsheets

\section{Service Learning}

2007

Lone Star College - Montgomery

- Designed and constructed scoreboard for vintage baseball team
Hometown, TX77333

GPA: 3.7

May 30, 1999

ACT (Composite): 30

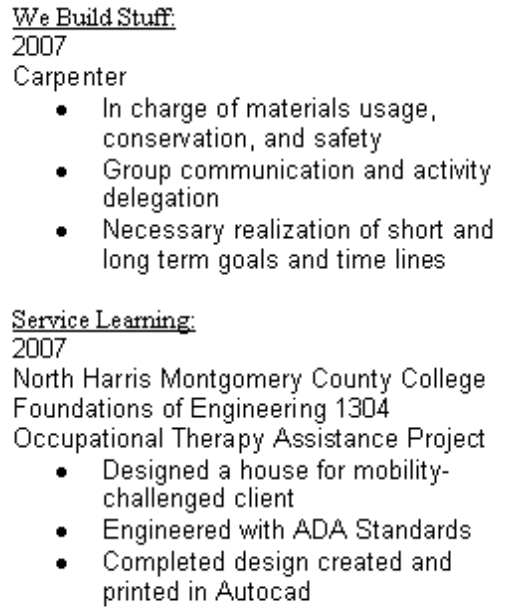
conservation, and safety

- Group communication and activity delegation

- Necessary realization of short and long term goals and time lines

\section{Service Learning:}

2007

North Harris Montgomery County College Foundations of Engineering 1304

Occupational Therapy Assistance Project

- Designed a house for mobilitychallenged client

- Engineered with ADA Standards

- Completed design created and printed in Autocad

Skills:

- Proficient in Autocad

- Microsoft Office

- Quickbooks

- $\mathrm{C}++$ Programming

- Bilingual - Spanish

- Carpentry

- Paint / Drywall

- Basic Electrical

Figure 2. An Example of a Resume in Need of a Graphic Designer multiple and inconsistent fonts 
Perhaps the saddest of the student mistakes was providing the bare minimum. Figure 3 and Figure 4 give examples of two students whose resumes communicate little skill to potential employers. Ironically, "Ms. O’Dell” and "Stu" were two of the brightest, most accomplished, and highest scoring students in the class. Both of them suffered from a misconception that their accomplishments were not important to prospective employers.

\section{Part 2: Attend a Resume Seminar}

The first step in correcting the errors was for students to attend a resume seminar at Lone Star College - Montgomery. These one-hour sessions are offered periodically for all students. Each engineering student was required to attend one session as part of this assignment. As proof of attendance, students receive a signed ticket, which was required as part of the grade for the assignment. According to the campus career counselor, session content may vary based on the student needs, but most often consists of resume mechanics, as well as do's and don'ts of resume writing $^{6}$. Additionally, a packet is distributed to all attendees that includes a segment on getting started, several example resumes, writing tips, and a long list of action verbs ${ }^{7}$.

While students attended, the course instructor scanned the resumes, noting major corrections required on each. Those notes were recorded on the student resume, but the instructor also kept a record of common mistakes. During class time, a short discussion was held where the common mistakes were brought to light and briefly commented on. Below is an outline of the advice offered within the classroom:

Questions to Consider:

- Who are you writing this for?

- How long do they have to look at it?

- What do you want them to know?

- Why are you different from everyone else?

General Guidelines:

- Fit it on one page (and fill that page)

- Sections to include

o Objective

o Summary of Qualifications

o Education

o Work Experience

o Skills

- No spelling or grammar errors

o Periods only go at the end of a complete sentence 


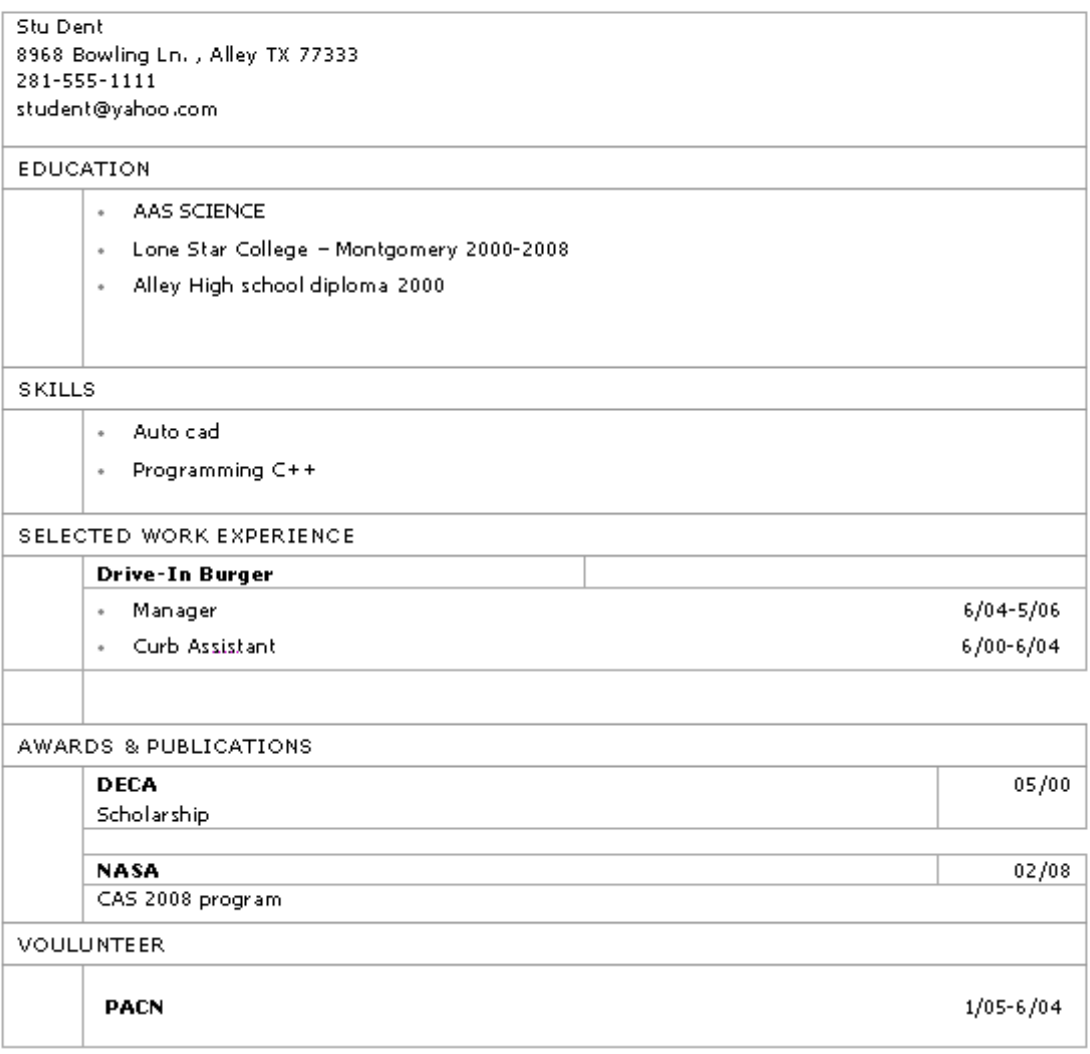

Figure 3. An Example of a Resume Lacking Content

Proceedings of the 2009 ASEE Gulf-Southwest Conference

Baylor University

Copyright $($ ) 2009, American Society for Engineering Education 
Name:

- M. O'Dell

- 2225557777

Education:

- ElementarySchool: American School of Torreon

- Middle School:St. Joseph CatholicSchool

- High school: Hometown High School

- College: Lone Star College System, Montgomery College

Skills:

- Auto Cad Knowledge

- Programming in $\mathrm{C}++$

- Good working with Micros oft PCS and MACS

Work Experience:

- Big Company LLP

$$
\text { - Secretary }
$$

- The High Price Hotel

- Hostess

Figure 4. Another Example of a Resume Lacking Content

Proceedings of the 2009 ASEE Gulf-Southwest Conference

Baylor University

Copyright $\left(C_{0}\right.$ 2009, American Society for Engineering Education 
Additional Notes:

- Objective should inform the reader what type of position you want now

o Not where you hope to be in 2, 5, or 10 years

- Some things may be trivial to you, but not to others

o Don't be too trivial

- Education

o List dates of attendance

o Indicate anticipated degree or transfer

- "Associate of Science - anticipated Fall, 2008"

- “Anticipated transfer to University of Houston, Spring, 2009"

o Key Coursework

- Foundations of Engineering

- Service Learning

- Contact information

o Name

o Address

o Phone

- Email address

o Make sure it works

o Use a respectable name

- References

o Put on another sheet

o Omit "Available on request"

\section{Part 3: Update the Resume}

Once students had specific feedback from an engineering instructor and a better understanding of resumes from the career center seminar, they wrote an updated version of their resume. Again, the instructor perused it for necessary changes.

\section{Part 4: “Resumania” One-on-One Counseling}

Additionally, they were asked to attend a session at the Lone Star College- Montgomery career center titled "Resumania". In this session, students spent time one-on-one with a career counselor, discussing specific points that needed work within the resumes. Again, students were asked to return with a ticket as proof of their attendance. The career center staff shared some of the common items they review with students ${ }^{6}$ :

- Be organized.

- Make the resume easy to read.

- Consider what the employer wants.

- Describe experience in relationship to what the employer wants.

- Make the objective clear and concise.

- Avoid spelling mistakes.

- Make the graphical layout consistent.

- Avoid the use of unprofessional email addresses.

Proceedings of the 2009 ASEE Gulf-Southwest Conference

Baylor University

Copyright $\Subset$ 2009, American Society for Engineering Education 
- Reference name and contact information should not be listed on the resume.

- Engineers typically make a resume into a life history. Do not include everything done in previous jobs. Be selective.

- The author should be comfortable with the contents since he/she needs to defend every line.

\section{Part 5: Create a Final Resume}

With more personalized input from both faculty and career center advisors, students produced the final draft of a resume as the last graded portion of this project. As hoped, the content and presentation of information within the resumes was much improved.

The newly enhanced set of student resumes was transferred to an engineering manager and human resources manager at a local engineering company, Hughes Christensen - a division of Baker Hughes, Inc. Both had agreed to evaluate the student resumes and provide feedback, rating each on a scale of 1 to 10 . After reading through and marking up the resumes, the two evaluators met with the instructor and commented on the highlights of each resume. Those comments were recorded and compiled by the instructor and re-presented to the class under the title "What's Important to an Employer":

- Format

o Easy to read

o Visually pleasing

o Visual separation of sections

o Single font (unless you get graphical design advice)

o Fill the page (don't leave too much white space)

o Single column

o It should look "pretty"!

- Objective

o This is important!

o Should be specific

o What are you looking for?

o What are your interests?

o Make it relevant to the position

- Put your most relevant and recent qualities first

o For students, that's education

o List it above a summary of qualifications

- List job and education experiences in chronological order o Start with the most recent

- Education

o Show the school you are attending

o Indicate the months of attendance (not semesters)

o List key courses

- The ones that matter to this employer

o Give your GPA

- No GPA $\rightarrow$ assumed bad 
o List your high school

- Shows a tie to this area

- Gives data to compare

- Employment experience

o No job is too weak to list

o Jobs are better if there is a progression

o Layout:

$\begin{array}{lll}\text { - Date Company } & \text { Position }\end{array}$

- Skills

o Technical skills are most important

o AutoCAD

o Programming

o Microsoft Office

- Excel

- Word

- Access

- PowerPoint

- Leadership Positions

o Clubs, Robotics, Boy Scouts, Sports, Volunteer Activities

Much of this information had been conveyed in the resume sessions with the career center, but this presentation was more carefully considered by the students. This advice carried greater weight because it came from a source of potential employment. Students were most surprised that the appearance was important to an engineering employer and that their high school and community college education could help them win jobs.

After the assignment was complete and the students had another opportunity to make modifications to their resume, they were asked to submit their final version. Figure 5 shows the improvements of "Tess" who started with a four-page resume listing nearly every role at every employer. The improved version is more succinct and better presented. Figure 6 and Figure 7 are updated copies of resumes from Stu and Ms. O'Dell. Previous versions had been sparse, but the newer copies show a much more complete and compelling work and education history.

\section{Conclusions}

1. This assignment was the first time many of the students had considered what a resume is and what it should include. Fortunately, it brought that particular thought to the forefront of the students' minds before they were in the midst of a job search. In fact, student reactions to the assignment indicated that many had never considered what would be involved in a job search.

2. Gaining student interest was not difficult. When the students recognized the more direct link between the assignment and personal income, their interest was piqued. It also demonstrated that their instructor was interested in their professional success and not just grades. 
3. The most valuable benefit of this project was the insight students gained. As noted above, career advisors often encourage job seekers to present what the employer wants to see. However, the most frequent question that students asked was, "Do employers want to know that?" Students did not understand what facts are important to employers when they are making hiring decisions. Assignments like the one presented here help students break into that treasure of information.

4. An additional bonus of this project that certainly cannot be overlooked was the connection to a potential employer. As always, collaborations between institutions of higher learning and industry yield benefits for both parties. In this case, the students had an added bonus. The timing of the project worked so that Hughes Christensen was conducting a search for summer interns. Some of the higher-rated resumes found their owners in consideration for summer employment.

5. The improvement in the student resumes was obvious. Common mistakes were corrected, and students left this course with improved job search skills. Obviously, the examples above can still be improved, but the positive change in all cases is clear.

6. Discussion of the common mistakes and omissions within class took place during two separate class meetings, totaling approximately 25 minutes. Given the effectiveness and minimal impact on class time, this assignment will become a permanent part of the LSC-Montgomery Foundations of Engineering course.

7. Similar versions of this project can be readily implemented at other institutions. Key to the success of this format are willing faculty, an on-campus career center, and a relationship with industry professionals. Time investment from the faculty and industry partners is minimal, and career centers are typically searching for ways to interact with students. In absence of a career center, students could be referred to resume books or handouts that are widely available, and iterations of the assignment could be handled by additional industry professionals rather than college staff. Alumni, personal contacts, or companies that recruit from the school would all serve as possible contacts when already-established industry relationships are lacking.

8. Multiple faculty working together could further improve the project. Since the key to an effective resume is to highlight the skills a prospective employer is looking for, repeating the process with a variety of employers during different academic years would give the student some idea how different job opportunities require them to highlight different skill sets. As an example, one employer may be looking for design skills and another, interpersonal skills. It may also spur students to think more clearly about the type of work they would find truly rewarding. 


\section{Tess Case \\ 123 Elm St. \\ Spring, TX 77373 \\ Cell: (281)555-9876 \\ tess_case@hotmail.com}

Objective: To work for an engineering firm as a computer drafting designer.

Education: - Lone Star College (Montgomery and North Harris) (2006 - 2008)

- Science Associate degree achieved by Dec. 2008

- GPA achieved 3.7

- Service learning done in Montgomery College - Conroe Center Campus - Design and creation of a book drop for the library

- Completed second semester of the Sophomore year of an engineering degree

- Placed in President's List on both college

- Placed in Honor Programs courses at Montgomery College

- Math award for outstanding performance at North Harris College on two semesters

Experience: Computer and Engineering 10/2007 to present - Big Oil, Conroe TX

- Utilize computer drafting design skills to assist in the project designs and help keep the company up to date working along with the engineering group.

- Assembling of manufacturing parts as need it

Transportation/Distribution $7 / 2003$ to $10 / 2007$

- Long Haul Inc, Houston Distributing Company - Houston TX

- Handled and transported merchandise working independently and with attention to detail.

Customer Service/Management 1/1999 to 3/2006

-Burger Place - Spring TX, Movies \& Stuff - Rep. of Panama

- Managed team of workers with responsibility, respect and customer focus.

- Management of store, computers, finances and safety regulations

Skills and Abilities:

- Technical Sketching since 1993

- Computer skills: Micros oft Office, AUTOCAD 2008-including 3-D, Basic C++ programming, SolidW orks 2007-COSMOSWORK integrated

- Bilingual - read, write, and speak Spanish and English

Figure 5. An Example of an Improved Resume (See the original in Figure 1.) 
Stu Dent

8968 Bowling Ln. , Alley TX 77333

Cell: $281-555-1111$

studentidyahoo.com

Objective: To obtain an internship and continue to advance my education.

\section{Education}

- Received Associate of Science

GPA : 3.45

December, 2007

- Lone Star College-Montgomery 2000-2008

- Inorganic Che mistry 1 and 2

- Math: Trigonometry, Pre-calculus, Calc ulus 1 and 2

- Engineering: Intro to Engineering 1 and 2

- Service Leaming

- Texas A\&M University

- Mechanical Engineering

- Jurior level June 2009

\section{Work experience}

- Lone Star College-Montgomery

June-July 2008

- Taught youth robotic and energy classes

- Drive-In Burger

2000-2006

- Manager: disse minating information, training and task a 15 person team, fixing equipment, follow safety regulations

- Curb Assistant: customer service, money

- Nursery Customer Representative

1999-2000

- Register working with: money, customers

- Landscaping irwolving: customer request, proble m solving geometrical layouts, transporting heavy materials safely and timeliness

- Convenient Store clerk

1995-1999

- Worked register, stocked floor, customer Service, closing of store

Skills

- Mechanical

- Small and automobile engine repair, dis assembly, and assembly

- Machining: lathe, drill press, and band saw

- Electrical

- Automobile, home and small appliance wiring

- Computers

- Auto CAD, Programming in CH, Office 2007

- Fabrication

Awards

- Outdoor play equipment, flooring roofing, sheetrock, plumbing, wall framing and wood working

- NASA Aerospace scholars program

2008

- Mission Construction : astronomical calculations, rover construction, risk manage ment, and team management

- DECA Scholarshí

1999-2000

- Strong debate and interpersonal communication skills

Figure 6. Another Example of an Improved Resume

(See the original in Figure 3.)

Proceedings of the 2009 ASEE Gulf-Southwest Conference

Baylor University

Copyright (C) 2009, American Society for Engineering Education 


\title{
M. O'Dell
}

\author{
321 Oak St. \\ Hometown, TX 77777 \\ (222) $555-7777$ \\ modellstudent@hotmail.com
}

OBJECTIVE: To obtain a position where my knowledge and slills can be used.

SKILLS

- Excellent communication and service slills

- Auto Cad knowledge

- Bilingual

- Fluent in Engish and Spanish

- Programming in $\mathrm{C}$ and $\mathrm{C}++$

- Excellent working with both PCS and MACS

EDUCATION

- Hometown High School, Hometown, TX

- Graduated in May 2006

- Graduated in my Junior year

- Montgomery College, Conroe, TX

- Pursuing a Civil Engineering Degree

- Anticipated transfer to University of Houston Fall, 2008

- Expected Graduation Date: May 2011

- Key Coursework

- Engineering 1404 and 1405

- Chemistry

- Programming in $\mathrm{C}$ and $\mathrm{C}++$

\section{SUMMARY OF EXPERIENCE}

- Programming

- Experience working with $\mathrm{C}++$ and $\mathrm{C}$

- Lego Robotics Slills

- Auto Cad

- Worked with OTA customers to design a handicap accessible house

- ADA Standards Knowledge

WORK EXPERIENCE

Big Company, LLP.

Shipping Manager

2007-Present

- Find over 120 trucks a month that will ship the material in a timely manner to over 15 states

Figure 7. Another Example of an Improved Resume

(See the original in Figure 4.) 


\section{References}

1. Sims, K. 2003, "Senior Year Job Search Strategies: Five Steps from Your Launch to Your Landing," Black Collegian, Vol. 34, No. 1, p. 10.

2. Pauschke, J., Ingraffea, A. 1996, "Recent innovations in undergraduate civil engineering curriculums," Journal of Professional Issues in Engineering Education \& Practice, Vol. 122, No. 3, pp. 123-133.

3. Staff, 2006, "Sides Gird for Engineering License Battle: 30 Credits Over Degree,” Engineering News-Record, Vol. 257, No. 17, p. 31.

4. Shuman, L., Besterfield-Sacre, M., McGourty, J. 2005, “The ABET 'Professional Skills' - Can They Be Taught? Can They Be Assessed?,” Journal of Engineering Education, Vol. 94, No. 1, p. 41.

5. Engineering Accreditation Commission, 2008, Criteria for Accrediting Engineering Programs, Baltimore, ABET, Inc.

6. Haynes, M. and M. Crouse. 11 Dec 2008. Personal interview.

7. Lone Star College - Montgomery Career Services. 2008. Resume Writing and Cover Letter Information Packet. Conroe, TX: Lone Star College - Montgomery.

MICHAEL J. KRALL

Mike Krall is Professor of Engineering as well as Department Chair of Chemistry, Physics, Engineering, and Geology at Lone Star College - Montgomery, in Conroe, TX. He is the founding faculty of the LSC-Montgomery Engineering Transfer Program and developed the curriculum for each course in the sequence. His passion for student success and the teaching and learning process guides his work in both engineering and physics education. Mike has also served on the State of Texas science vertical team for curriculum alignment.

PAUL PASTUSEK

Paul Pastusek is an optimization engineer and business consultant to the oilfield industry. He has an MBA from the University of Houston and a BSME from Texas A\&M University. He is a Registered Professional Engineer, holds twenty four US patents and has written nine papers on drilling technology. During his 30 year career at Baker Hughes Paul has held positions as a: Researcher, Engineering Manager, Product Manager, Manager of Marketing, Staff Engineer, and Research Manager. He has led several teams that received Meritorious Engineering Awards for new products. He is active in encouraging engineering and science education and is a member of the local BEST Robotics advisory board. 